\title{
The Influence of Overconfidence, Herding Behavior, and Risk Tolerance on Stock Investment Decisions: The Empirical Study of Millennial Investors in Semarang City
}

\author{
Dea Adielyani \\ Wisnu Mawardi \\ Management Department, Diponegoro University, Indonesia \\ Author correspondence: dea.adielyani98@gmail.com
}

\begin{abstract}
The objective of this research is to examine the effect of overconfidence, herding behavior, and risk tolerance to the stock investment decisions. The hypotheses are overconfidence, herding behavior, and risk tolerance have a positive and significant effect on investment decisions. This study is quantitative research, with the population is millennial investors in Semarang City, Central Java, Indonesia. The research used 98 respondents was taken using purposive sampling. The data collected through questionnaires with Google form. The method of data analyze used multiple linier regressions with the application of Statistical Package for the Social Sciences (SPSS) version 22. The results showed that the overconfidence, herding behavior, and risk tolerance provided a positive and significant effect on stock investment decisions of millennial investors in Semarang City.
\end{abstract}

Keywords: Herding behavior; Millennial investors; Overconfidence; Risk tolerance; Stock investment decisions.

Abstrak. Penelitian ini bertujuan untuk menguji pengaruh beberapa variabel independen, yaitu overconfidence, herding behavior, dan risk tolerance terhadap keputusan investasi saham. Hipotesis yang diajukan dalam penelitian ini adalah overconfidence, herding behavior, dan risk tolerance berpengaruh positif dan signifikan terhadap keputusan investasi saham. Populasi dalam penelitian ini adalah investor milenial di Kota Semarang, Jawa Tengah, Indonesia. Sampel yang digunakan sebanyak 98 responden dengan menggunakan teknik pengambilan sampel purposive sampling. Pengumpulan data dilakukan melalui penyebaran kuesioner dengan alat bantu Google form, sedangkan teknik analisis data yang digunakan adalah analisis regresi berganda dengan menggunakan aplikasi SPSS (Statistical Package for the Social Sciences) versi 22. Hasil penelitian ini menunjukkan bahwa variabel overconfidence, herding behavior, dan risk tolerance berpengaruh positif dan signifikan terhadap keputusan investasi saham pada investor milenial di Kota Semarang. 
Kata Kunci: Herding behavior; Investor millenial; Keputusan investasi saham; Overconfidence; Risk tolerance.

Article Info:

Received: April 17, 2020

Accepted: July 20, 2020

Available online: August 7, 2020

DOI: http://dx.doi.org/10.30588/jmp.v10i1.691

\section{BACKGROUND}

A capital market is one of the tools deemed effective to accelerate the development and economic growth of a country, especially in Indonesia. If the mobilization of public funds through financial institutions and capital markets has been able to run well, it is expected that the development of fund sourced from abroad, such as foreign loans will be increasingly reduced (Aprillianto, Wulandari, \& Kurrohman, 2014). The presence of the capital market is considered capable of developing production sectors so that it will enhance a country's economic growth (Sunariyah, 2011). Public interest in investing in financial products and services in the capital market is still low at $0.11 \%$. The highest percentage of public investment is still in the banking sector at $57.28 \%$, followed by insurance $11.18 \%$, corporate financing $6.33 \%$, pawnshop $5.04 \%$, and pension $1.53 \%$ (Otoritas Jasa Keuangan, 2017).

But over time, public awareness to invest in the capital market has increased. Data shows that there are at least 16,000 new investors in Central Java until the end of July 2019, exceeding the 9,000 investors target set by the Indonesia Stock Exchange (IDX) Semarang. This new number of investors is higher than 2018 which only recorded 11,000. Other data explain the highest number of investors Semarang City compared to other districts in Central Java. During 2018, the number of investors in Semarang City reached 23,992 securities sub accounts with 18,841 active single investors identification or SID's and 2,201 logins. While the second rank is Surakarta City with 9,777 investors with 7,930 active accounts and 735 logins. Then, Rembang District has the lowest number of investors in Central Java. The number of investors in Rembang regency is recorded at only 580 investors and 518 active SID's and 66 logins (IDX Semarang, 2019).

Apart from the number of investors, the transaction value also tends to increase, as of November 2019 the value of capital market transactions in Central Java reached Rp4.61 trillion. Around $36.77 \%$ or Rp1.69 trillion originated from Semarang City (Bisnis.com, 2017). The data shows that in 2016 there was an increase of $22.913 \%$, in 2017 there was an increase of $30.621 \%$, in 2018 an increase of $37.642 \%$, and the highest increase in 2019 which was amounted to $56.191 \%$ (IDX Semarang, 2019).

To encourage public interest in investing in the capital market, the Semarang Indonesia Stock Exchange (IDX Semarang) routinely conducts educational activities through seminars, workshops, and the Capital Market School (SPM) twice every week. The education results show a significant increase in the number of millennial investors, reaching $15 \%$ to $20 \%$, from 13,000 investors to 15,000 active investors buying and selling shares (IDX Semarang, 2019). 
Millennials sometimes make irrational investment decisions and often are not based on financial theory. Cognitive bias is a thought process that is not based on rational considerations and is not complemented by sound reasons. As a result, there will be perversion, judgment lapses, or what is often called irrational (Asri, 2015). The phenomenon of overconfidence in influencing investment decisions can be seen from when stock prices decline, investors who feel they have knowledge and intuition often ignore the risk limits that they can bear. Likewise, when stock prices increase, overconfident investors will assume that stock prices will continue to rise (Kompas.com, 2019).

Some bias variables that influence investors in decision-making actions include overconfidence behavior, risk tolerance, and herding behavior. Herding in financial markets tends to be identified as investor behavior where the investor mimics other investors in making investment decisions. Herding behavior occurs because of something that can lead investors to follow other investors in making decisions. An investor who behaves herding will tend to group in making decisions with the belief that behaving herding helps investors in obtaining useful and reliable information (Luong \& Doan, 2011). Inefficient market conditions are indicated from the frequent market prices of some stocks are too high (overvalued) or too low (undervalued) than they should be so that investors may be able to take advantage of the opportunity to obtain abnormal returns. Investor herding behavior in making investment decisions can be seen from the trading volume of its shares (Asri, 2015).

When making investment decisions, an investor always considers and minimizes risk. Risk tolerance is a number of negative impacts (such as risks) that can be accepted and dare to be taken by someone to achieve their goals. Mahardika (2017) explained that risk tolerance is the extent to which investors are willing to assume a higher risk for their investment. Halim (2015) stated that there are three types of investors from risk tolerance behavior, namely risk seeker, risk neutral, and risk adverter. A person who has a high risk tolerance behavior, then he is more likely to choose a high risk investment. If someone has a low risk tolerance behavior, then he is more selective when making stock investment decisions.

Research on overconfidence, herding, and risk tolerance behavior toward investment decisions has been carried out, but the results are different. Menike, Dunusinghe, and Ranasinghe (2015), Budiarto and Susanti (2017), and Pradikasari and Isbanah (2018) based on the results of their studies concluded that overconfidence and herding behavior had a positive and significant effect on investment decisions. Unlike the research by Wulandari and Iramani (2014), the opposite results show that overconfidence has a significant negative effect on investment decisions. The study of Javed, Bagh, and Razzaq (2017), Putri and Isbanah (2020), Jin, Yan, Xi, and Liu (2016), Menike et al. (2015), and Waweru, Munyoki, and Uliana (2008) mentioned that herding behavior has a positive and significant effect on investment decisions, but the results of other studies conclude that herding behavior has a negative and significant effect on investment decisions (Lowies \& Cloete, 2016). The research of Pradikasari and Isbanah (2018) found that the effect of risk tolerance on investment decisions was positive and significant, but the study of Budiarto and Susanti (2017) produced the findings of a negative and significant effect on these variables. 
Based on the existing research gap, this study tries to explore the factors that contribute to stock investment decisions among millennials. This study aims to analyse the effect of overconfidence, herding, and risk tolerance on stock investment decisions, a study of millennial generations in Semarang City. The results of the study are expected to be a source of reference and contribution in enhancing the development of the science of financial management, specifically financial behavior in making stock investment decisions.

\section{THEORETICAL REVIEW}

Wulandari and Iramani (2014) explain that investment decisions are policies or decisions taken from one or more assets that aim to benefit in the future. Understanding investment decisions from a financial point of view (financial assets) is a policy of someone in using funds to be saved in the form of savings, current accounts or deposits that can be used when there is an urgent need. While the view of the real sector (real assets) of investment decisions is the decision of someone to invest the money or assets owned by buying a house, land, and others, so that it can be used at any time or for profit. An investment decision is a decision taken to place a certain amount of funds or capital into a particular type of investment to benefit in the future (Wardani \& Lutfi, 2017).

Factors that influence decision making are: all things that are tangible or intangible, rational or irrational in decision making need to be calculated properly; all investment decisions in the future are expected to become one of the considerations for the success of the organization; all decisions should not be based on personal interests, but the interests of others must also be considered, decision-making is an action related to one's mental, and must be changed into physical actions (Terry \& Rue, 1988). This requires a relatively long time; and to find out whether every decision taken was effective or not needed an evaluation.

\section{Effect of Overconfidence on Stock Investment Decisions on Millennial Investors}

Overconfidence is an excessive feeling of confidence. Overconfidence has an impact that investors will overestimate and underestimate the predictions made because investors will act to exaggerate their capabilities. Investors with a high level of confidence tend to be more willing to take risks, where an investor who is rational will always try to maximize return and minimize risk (Kartini \& Nugraha, 2015).

Budiarto and Susanti (2017) argue that overconfidence is excessive selfconfidence that investors have in investing with their knowledge and abilities. Overconfidence is an unreasonable trust in intuitive reasoning, cognitive ability. Wulandari and Iramani (2014) state that overconfidence results in an investor being overestimated against excessive predictions made, knowledge, and capabilities possessed by investors. Cheng (2007) says that overconfidence is the most common characteristic encountered in humans which reflects a person's tendency to overestimate his ability, his likelihood of success. and the probability that a person will obtain positive outcomes and accuracy of his knowledge.

Odean's study (1998) shows that investor trading overconfidence is more than rational investors and doing so decreases their average utility, because investors too 
believe that trading is too aggressive when they receive information about the value of security. Similar results from several studies showed that overconfidence has a positive effect on investment decisions (Riaz \& Iqbal, 2015; Javed et al., 2017; Budiarto \& Susanti, 2017; Pradikasari \& Isbanah, 2018). Based on the description above, the following first hypotheses can be proposed:

\section{H1: Overconfidence has a significant positive effect on investment decisions.}

\section{Effect of Herding Behavior on Stock Investment Decisions on Millennial Investors}

Lao and Singh (2011) states that herding behavior is one of the financial behaviors that portrays investors following other investors when making investment decisions. This behavior of following other investors is carried out due to hesitation in making stock investment decisions. Therefore, investors decide to follow other investors, hoping to minimize risk. Hwang and Salmon (2004) explain imitating decisions observed from other investors or movements in financial markets rather than following their own beliefs and information. This means that investor notifications change in some trends in the market when other investors start making changes in their portfolios.

Herding behavior in financial markets is identified as a tendency of investor behavior to follow other investors in decision making actions (Dar \& Hakeem, 2015). Meanwhile, according to Liem and Sukamulja (2017), herding behavior is a bandwagon behavior carried out by one investor following another investor for various reasons and conditions.

The study of Maina, Munyoki, and Uliana (2008) and Javed et al. (2017) found the results that herding behavior had a positive effect on investment decisions. Likewise, research by Putri and Isbanah (2020) concluded that herding had a significant effect on investment decision making. Based on the description above, the following second hypotheses can be proposed:

\section{H2: Herding behavior has a significant positive effect on investment decisions.}

\section{Effect of Risk Tolerance on Stock Investment Decisions on Millennial Investors}

Risk tolerance is the level of risk tolerance received by an investor in making investment decisions. According to Tandelilin (2010), risk tolerance is the tolerance or the willingness of investors to bear certain risks for each expected level of return. Factors such as age, gender, education, income, and experience will influence the level of risk tolerance of a person in making investment decisions. Millennials tend to choose high-risk and aggressive stock investments (Kompas.com, 2019). Someone will tend to take stock investment decisions bolder than others if they have a high risk tolerance.

Research from Wulandari and Iramani (2014), concluded that risk tolerance has a positive effect on investment decisions. Other research which was conducted by Pradikasari and Isbanah (2018) also has the result that risk tolerance has a positive effect on investment decision making. Putri and Isbanah (2020) stated that risk averse and risk perception have a significant effect on investment decision making. Based on the description above, the following third hypotheses can be proposed: 


\section{H3: Risk tolerance has a significant effect on investment decision making.}

\section{RESEARCH METHODS}

This study uses quantitative research methods with primary data, which are based on the philosophy of positivism in certain populations or samples, with the aim of testing the hypotheses that have been proposed (Sugiyono, 2017). The research is done by building hypotheses and testing them empirically (Ferdinand, 2014).

The population in this study is millennial investors, who aged between 17 to 40 years or born among 1980-2002 (United State Census Bureau) who invest in Semarang City. According to data from the Indonesia Stock Exchange (IDX) Semarang, the number of millennial stock investors in Semarang City in 2018 will be 5,652 people. After calculated using the Slovin formula (Sugiyono, 2017), the sample obtained was 98 respondents. Sampling was carried out using a purposive sampling method with considerations: he or she has been officially registered as one of the investors in the capital market, has a single investor identification (SID) aged 17-40 years, and domiciled in Semarang City.

The variables in this study consist of the dependent variable is investment decisions, and the independent variables are overconfidence, herding behavior, and risk tolerance. The investment decisions variable are measured by three indicators, namely return on investment, risk, and the time period (the time factor) (Budiarto \& Susanti, 2017). The overconfidence variable is measured by four indicators, namely accuracy in choosing investments, trusting in one's own abilities, trusting in the knowledge possessed, and confidence in choosing investments (Budiarto \& Susanti, 2017). The herding behavior variable is measured by four indicators, namely the decision to buy and sell shares by looking at other investors, choosing stocks in trading by looking at other investors' shares, seeing the trading volume of other investors' shares, and the length of time to save shares based on other investors or herding speed (Waweru et al., 2008; Putri \& Isbanah, 2020). The risk tolerance variable is measured by three indicators, namely income indicators used for speculative investments, purchase of shares without consideration, and investing in stocks that provide large returns (Budiarto \& Susanti, 2017).

Data collection techniques for these four variables use a survey method through questionnaires using Google forms. Measurement of those variables using a Likert scale from 1 to 5 that has intervals from strongly disagree to strongly agree. The data collected in this study is tested and analyzed by validity and reliability test, classic assumption test, multiple linear regression, $\mathrm{F}$ statistical test, $\mathrm{t}$ statistical test, and coefficient of determination (Ghozali, 2017).

\section{RESULTS AND DISCUSSIONS}

\section{Characteristics of Respondents}

Respondents in this study are predominantly female, aged 17-22 years, educated in high school/vocational school, work as students, monthly income is less than 1 million rupiah, and investment time is less than one year (Table 1). 


\section{Validity and Reliability Test Results}

The validity testing is done by using corrected item-total correlation, while the reliability testing is conducted by looking at the magnitude of the Cronbach's Alpha coefficient. The test results show that the validity for all indicators are valid, because $\mathrm{r}$ count $>$ r-table 0.166 and reliable with Cronbach's Alpha coefficient $>0.70$ (Table 2).

Table 1. Characteristics of Respondents

\begin{tabular}{|c|c|c|}
\hline Information & Amount & $\%$ \\
\hline \multicolumn{3}{|l|}{ Gender } \\
\hline Male & 39 & 39.8 \\
\hline Female & 59 & 60.2 \\
\hline \multicolumn{3}{|l|}{ Age } \\
\hline $17-22$ years old & 52 & 53,1 \\
\hline 23-28 years old & 10 & 10,2 \\
\hline 29-34 years old & 19 & 19,4 \\
\hline $35-40$ years old & 17 & 17,3 \\
\hline \multicolumn{3}{|l|}{ Education } \\
\hline SMA/SMK & 46 & 46,9 \\
\hline Diploma (D3) & 6 & 6,1 \\
\hline Bachelor Degree (S1) & 33 & 33,7 \\
\hline Master Degree (S2) & 13 & 13,3 \\
\hline \multicolumn{3}{|l|}{ Profession } \\
\hline Student/College Student & 56 & 57,1 \\
\hline Governments/Private employees & 24 & 24,5 \\
\hline Entrepreneur & 17 & 17,3 \\
\hline Others & 1 & 1,0 \\
\hline \multicolumn{3}{|l|}{ Income (Rupiah) } \\
\hline$<1.000 .000$ & 39 & 39,8 \\
\hline $1.000 .000-4.000 .000$ & 31 & 31,6 \\
\hline $5.000 .000-8.000 .000$ & 19 & 19,4 \\
\hline$>9.000 .000$ & 9 & 9,2 \\
\hline \multicolumn{3}{|l|}{ Investment Time } \\
\hline$<1$ Year & 32 & 32,7 \\
\hline 1-3 Years & 53 & 54,1 \\
\hline 3-5 Years & 11 & 11,2 \\
\hline 5-10 Years & 1 & 1,0 \\
\hline$>10$ Years & 1 & 1,0 \\
\hline
\end{tabular}

\section{Normality Test Results}

The normality test through a histogram that shows a normal distribution pattern which is a graphic image in the middle and follows the diagonal line. The statistical test results used Kolmogorov Smirnov (K-S) with a number of 0.055 and a significance of $0.200>0.1$, so that the data can be stated normally distributed.

\section{Heteroscedasticity Test Results}

The heteroscedasticity test results used scatterplots graphs that show the data is scattered and does not make any patterns. Based on the glacier test, the value of overconfidence sig is 0.433 , herding behavior sig is 0.511 and risk tolerance sig is 
0.063 , they are greater than $5 \%$. This means that the variables of overconfidence, herding behavior, and risk tolerance are free of heteroscedasticity.

\section{Multicollinearity Test Results}

The results of multicollinearity test showed the amount of tolerance $>0.1$ and the VIF number in the range of more than 1 and less than 10. Based on the results of this test, it was stated that there was no multicollinearity.

Table 2. Validity and Reliability Test Results

\begin{tabular}{|c|c|c|}
\hline Variable and Indicator & r-count & Cronbach's Alpha \\
\hline Overconfidence & & 0.795 \\
\hline $\begin{array}{l}\text { Investment decisions on selected stocks are the right choice in } \\
\text { investing. }\end{array}$ & 0.765 & \\
\hline $\begin{array}{l}\text { Very confident that the ability possessed can help choose a good } \\
\text { investment for the future. }\end{array}$ & 0.799 & \\
\hline $\begin{array}{l}\text { Very confident that the knowledge possessed can help choose a } \\
\text { good investment for the future. }\end{array}$ & 0.739 & \\
\hline $\begin{array}{l}\text { Very confident that the investment decision on the selected } \\
\text { stock is very useful for the future. }\end{array}$ & 0.848 & \\
\hline Herding Behavior & & 0.877 \\
\hline $\begin{array}{l}\text { Another investor's decision to buy and selling shares has an } \\
\text { impact on investment decision. }\end{array}$ & 0.860 & \\
\hline $\begin{array}{l}\text { The number of certain shares traded by other investors } \\
\text { influences investment decisions. }\end{array}$ & 0.896 & \\
\hline $\begin{array}{l}\text { The decision of other investors to see the volume of stock } \\
\text { trading has an impact investment decisions. }\end{array}$ & 0.804 & \\
\hline React quickly to changes in other investors' decisions. & 0.861 & \\
\hline Risk Tolerance & & 0.818 \\
\hline Use income / money to invest speculative stocks. & 0.828 & \\
\hline Invest in shares without considering. & 0.899 & \\
\hline $\begin{array}{l}\text { The selected stock investment is an investment that provides a } \\
\text { large return. }\end{array}$ & 0.853 & \\
\hline Investment Decisions & & 0.721 \\
\hline $\begin{array}{l}\text { The rate of return obtained is equal to or higher than the average } \\
\text { rate of market return. }\end{array}$ & 0.809 & \\
\hline Currently selected stock investments do not provide much risk. & 0.843 & \\
\hline $\begin{array}{l}\text { Can predict the risk factor components that are related to stock } \\
\text { investments that change from time to time. }\end{array}$ & 0.749 & \\
\hline
\end{tabular}

\section{F-test, t-test, and R-square}

Testing the goodness of the model is done by the F-test, t-test, and R-square, which based on the results of calculations can be shown in Table 3. Based on Table 3, the regression equation [1] is as follows:

$$
Y=0.346+0.361 X_{1}+0.315 X_{2}+0.237 X_{3}+e
$$

The regression equation above has a positive sign of the regression coefficient. This equation shows that if the overconfidence, herding behavior, and risk tolerance 
variables have increased, the investment decisions on millennial investors in Semarang City will also increase. The next calculation results obtained Adjusted R-Square figure of 0.706. This result indicates that the contribution of independent variables, namely overconfidence, herding behavior, and risk tolerance, is able to explain the dependent variable, namely investment decisions by $70.6 \%$. While the remaining $29.4 \%$ is explained by other variables outside of the study. The result of the F statistical test was 78,801 and the significance value was 0,000 , smaller than 0.05 . Statistical F test results can be concluded that the model in this study can be used for further analysis.

Table 3. F-Test Results, t-Test, and R-Square Coefficients $^{\mathrm{a}}$

\begin{tabular}{llccccc}
\hline \multirow{2}{*}{ Model } & \multicolumn{2}{c}{ Unstandardized Coefficients } & $\begin{array}{c}\text { Standardized } \\
\text { Coefficients }\end{array}$ & t & Sig. \\
\cline { 2 - 5 } & B & Std. Error & Beta & & \\
\hline $1 \quad$ (Constant) & 0.346 & 0.272 & & 1.271 & 0.207 \\
& Overconfidence & 0.361 & 0.079 & 0.305 & 4.570 & 0.000 \\
& Herding Behavior & 0.315 & 0.071 & 0.374 & 4.432 & 0.000 \\
& Risk Tolerance & 0.237 & 0.066 & 0.306 & 3.574 & 0.001 \\
\hline
\end{tabular}

${ }^{a}$ Dependent variable: Investment decisions.

Notes: R-Square: 0.715; Adjusted R-square: 0.706; F-count: 18.801; Sig.: 0.000.

Based on Table 3, it can be seen that the value of sig. of the overconfidence variable is $0.000<0.05$, so it can be concluded that the first hypothesis (H1), the overconfidence variable which has a positive effect on stock investment decisions is accepted. Sig value of herding behavior variable is $0.000<0.05$, so it can be concluded that the second hypothesis $(\mathrm{H} 2)$ which states that the variable has a positive influence on stock investment decisions is accepted. The last result is the value of sig of the risk tolerance variable is $0.001<0.05$, so it can be concluded that the third hypothesis $(\mathrm{H} 3)$ that the risk tolerance variable which has a positive influence on the investment decision on shares can be accepted too.

\section{Discussions}

The first result explains that there is a positive and significant influence of overconfidence on stock investment decisions. The acceptance of this first hypothesis indicates that higher the overconfidence, it will be higher the investment decision of shares to millennial investors in Semarang City. Then, it can be seen that millennial investors in Semarang City have high overconfidence behavior in their investment decisions. Millennial investors in Semarang City in taking action based on overconfidence behavior by considering various reasons, including the belief that their investment decisions on the selected stocks is a right choice for their investment, their capabilities and knowledge can help choose a good investment for the future. The belief in their investment decisions on selected stocks are very useful for the future.

Millennial investors need to improve all forms of experience, abilities, and knowledge in the capital market. Those needs to be fulfilled because of these actions are considered important when investors face critical conditions and the needs for action to take quick decisions without having to wait for the analysis process of any information that certainly requires a long time process. So, new investors who increasing their overconfidence attitude will make investment decisions more active and speculative. 
The results of this research support and clarify the results of previous research. Pradikasari and Isbanah (2018), Javed et al. (2017), and Budiarto and Susanti (2017) showed their findings that overconfidence has a positive and significant effect on stock investment decisions.

Herding behavior is proven to influence stock investment decisions. The result pointed that higher the herding behavior, it will be higher the stock investment decisions on millennial investors in Semarang City. It can be seen that millennial investors in Semarang City have high herding behavior in their investment decisions. Millennial investors in Semarang City in taking action based on herding behavior by considering the decisions of other investors in buying and selling shares, the number of certain shares traded by other investors, the decisions of other investors in viewing the trading volume of shares and changes in other investors' decisions regarding shares traded by other investors, the type of shares chosen by other investors, and the volume of shares traded on the capital market. It means that millennial investors in Semarang City tend to follow the actions of other investors and they rely more on collective information rather than personal information, resulting in volatility in stock prices. In addition, they act by following other investors on the assumption that such actions are able to facilitate them to capture useful and reliable information.

This study shows that stock millennial investors in Semarang City base their investment decisions on the decision to buy or sell shares and they react quickly to other investors' decisions in the hope of getting higher returns. The relationship of herding behavior and stock return can be explained that herding behavior will certainly have an impact on increasing the trading volume of stock investors. An increase in the volume of stock trading shows the higher frequency of transactions. High transaction frequency of a particular stock will make the stock more liquid. It shows that these stocks are increasingly in demand by investors. Investors will benefit if the shares are liquid because they are easier to transact, so there is an opportunity to get capital gains.

Herding behavior may emerge as a reaction from a reluctance to regret. Investors who suffered losses in the past certainly have deep regrets, so they choose to follow other investors or make future decisions in acting with the aim to be as good as their peers. Investors' actions following the masses have a positive impact on investment decisions. This research supports and clarifies the results of research conducted by previous researchers, namely Javed et al. (2017), Putri and Isbanah (2020), Jin et al. (2016), and Waweru et al. (2008) which found that herding behavior had a significant positive effect on investment decisions.

Results of the recent study revealed that risk tolerance affects stock investment decisions positively, so that the higher risk tolerance will influence the higher stock investment decisions on millennial investors in Semarang City. They will take actions based on risk tolerance behavior by considering income/money to invest speculative stocks, investing in shares without making a long consideration, and investing in selected stocks are the investments that provide a large return. It can be seen that millennial investors in Semarang City have high risk tolerance considerations in their investment decisions. Generally, an investor certainly expects a certain return with a smaller risk level or expects a high return with a certain risk. Someone could be bolder in making a decision, if they have a high risk tolerance, compared to those who have a low level of risk tolerance. 
The research conducted by previous researchers supports and clarifies this results from Pradikasari and Isbanah (2018) concluding that risk tolerance has a positive effect on investment decisions. From the findings of this research, it can be concluded that investors who like or have high risk in order to obtain greater profits, so they will have a high risk tolerance.

\section{CONCLUSIONS AND SUGGESTIONS}

\section{Conclusions}

Based on the data analysis and discussions, the conclusions of this study are overconfidence, herding behavior, and risk tolerance have positive and significant effects on stock investment decisions in millennial investors in Semarang City. Thus, the higher of overconfidence, herding behavior, and risk tolerance, the higher of stock investment decisions level of millennial investors in Semarang City. Conversely, the lower of overconfidence, herding behavior, and risk tolerance, the lower in stock decision making level of millennial investors in Semarang City.

\section{Limitations and Suggestions}

Limitations in this study include indicators in each variable using one opinion/ literature, and obtaining millennial investor data in Semarang City have not paid attention to the distribution in each region within Semarang City. Suggestion of the research results are indicators in each variables should have used more than one opinion/literature and the distribution of questionnaires using clusters, so that each region is fairy represented. The Indonesia Stock Exchange further enhances continuing education in the capital market for millennial investors, so that millennial investors have good investment knowledge or literacy in the capital market. Millennial investors in Semarang City need confidence or overconfidence of their knowledge and abilities in determining stock investment decisions, applying the principle of prudence in investing and remaining a guide for millennial investors, and must be more active in finding information about stocks that are chosen before making a decision.

\section{REFERENCES}

Asri, M. (2015). Keuangan Keperilakuan, Yogyakarta: BPFE UGM.

Aprillianto, B, Wulandari, N., \& Kurrohman, T. (2014). Perilaku Investor Saham Individual dalam Pengambilan Keputusan Investasi: Studi Hermeneutika-Kritis. $\boldsymbol{e}$ Journal Ekonomi dan Bisnis dan Akuntansi, 1(1), 16-31.

Bisnis.com (2017). Investor Saham di Semarang Banyak Generasi Milenial. Diakses tanggal 20 Desember 2019 di: https://market.bisnis.com.read/20171224/7/721143.

Budiarto, A., \& Susanti, S. (2017). Pengaruh Financial Literacy, Overconfidence, Regret Aversion Bias, dan Risk Tolerance terhadap Keputusan Investasi (Studi pada Investor PT Sucorinvest Central Gani Galeri Investasi BEI Universitas Negeri Surabaya). Jurnal Ilmu Manajemen (JIM), 5(2), 1-9.

Cheng, P. Y. K. (2007). The Trader Interaction Effect on The Impact of Overconfidence on Trading Performance: An Empirical Study. Journal of Behavioral Finance, 8(2), 59-69. 
Dar, F. A., \& Hakeem, I. A. (2015), The Influence of Behavioural Factors on Investors Investment Decisions: A Conceptual Model. International Journal of Research in Economics and Social Sciences, 5(10), 51-65.

Ferdinand, A. (2014). Metode Penelitian Manajemen (5th ed.). Semarang: Badan Penerbit Universitas Diponegoro Semarang.

Ghozali, I. (2017). Aplikasi Analisis Multivariate dengan Program IBM SPSS 21. Semarang: Badan Penerbit Universitas Diponegoro.

Halim, A. (2015). Analisis Investasi dan Aplikasinya dalam Aset Keuangan dan Aset Riil. Jakarta: Salemba Empat.

Hwang, S., \& Salmon, M. (2004). Market Stress and Herding. Journal of Empirical Finance, 11(4), 585-616. https://doi.org/10.1016/j.jempfin.2004.04.003.

Javed, H., Bagh, T., \& Razzaq, S. (2017). Herding Effects, Overconfidence, Availability Bias and Representativeness as Behavioral Determinants of Perceived Investment Performance: An Empirical Evidence from Pakistan Stock Exchange (PSX). Journal of Global Economics, 6(01), 1-13.

Jin, Y., Yan, M., Xi, Y., \& Liu, C. (2016). Stock Price Synchronicity and Stock Price Crash Risk. China Finance Review International, 6(3), 230-244. https://doi.org/10.1108/CFRI-05-2015-0047.

Kartini, K., \& Nugraha, N. F. (2015). Pengaruh Illusions of Control, Overconfidence dan Emotion terhadap Pengambilan Keputusan Investasi pada Investor di Yogyakarta. Ajie, 4(2), 114-122.

Kompas.com. (2019). Milenial Dominasi Investor Pasar Modal RI. Diakses 14 November 2019 di: https://money.kompas.com/read/2019/10/26/162200926.

Lao, P., \& Singh, H. (2011). Herding Behavior in the Chinese and Indian Stock Markets. Journal of Asian Economics, 22(6), 495-506.

Liem, W. K. A., \& Sukamulja, J. S. (2017). Perilaku Herding pada Indeks Sektoral dan Saham-Saham Terpilih. Mycological Research, 113(2), 207-221.

Lowies, G. A., Hall, J. H., \& Cloete, C. E. (2016). Heuristic-driven Bias in Property Investment Decision-making in South Africa. Journal of Property Investment \& Finance, 34(1), 51-67. https://doi.org/10.1108/JPIF-08-2014-0055.

Luong, L., \& Doan, T., (2011). Behavioral Factors Influencing Individual Investors' Decision Making and Performance. Master thesis, Umeå School of Business, Spring.

Mahardika, V. A. (2017). Pengaruh Overconfidence, Risk Tolerance, dan Faktor Demografi terhadap Pengambilan Keputusan Investasi Masyarakat Gresik. Doctoral Dissertation, STIE Perbanas Surabaya.

Maina, W. N., Munyoki, E., \& Uliana, E. (2008). The Effects of Behavioral Factors in Investment Decision-Making: A Survey of Institutional Investors Operating at the Nairobi Stock Exchange. International Journal of Business and Emerging Markets, 1(1), 24-41.

Menike, L. M. C. S., Dunusinghe, P., \& Ranasinghe, A. (2015). Behavioral Factors Influence on Investment Performance: A Survey of Individual Investors at Colombo Stock Exchange. In Proceedings of 10th Annual London Business Research Conference (pp. 10-11). 
Odean, T. (1998). Are Investors Reluctant to Realize Their Losses? Journal of Finance, 53(5), 1775-1798.

Otoritas Jasa Keuangan (2017). Sikapi Uangmu. Diakses 2 Desember 2019 di: http:// sikapiuangmu.ojk.go.id/public/content/files/2017_Materi\%0.

Pradikasari, E., \& Isbanah, Y. (2018). Pengaruh Financial Literacy, Illusion of Control, Overconfidence, Risk Tolerance, dan Risk Perception terhadap Keputusan Investasi pada Mahasiswa di Kota Surabaya. Jurnal Ilmu Manajemen (JIM), 6(4), 424-434.

PT Kustodian Sentral Efek Indonesia (2019). Laporan Sub-Rekening Efek di Jawa Tengah Periode 2015-2019. Jakarta: PT KSEI.

Putri, R. A., \& Isbanah, Y. (2020). Faktor-Faktor yang Mempengaruhi Keputusan Investasi pada Investor Saham di Surabaya. Jurnal Ilmu Manajemen, 8(1), 197209.

Riaz, T., \& Iqbal, H. (2015). Impact of Overconfidence, Illusion of Control, Self Control and Optimism Bias on Investors Decision Making: Evidence from Developing Markets. Research Journal of Finance and Accounting, 6(11), 22222847.

Sugiyono, S. (2017). Metode Penelitian Kuantitatif, Kualitatif, dan R\&D. Bandung: CV Alfabeta.

Sunariyah, S. (2011), Pengantar Pengetahuan Pasar Modal. Edisi Keenam. Yogyakarta: UPP STIM YKPN.

Tandelilin, E. (2010). Portofolio dan Investasi. Yogyakarta: Penerbit Kanisius.

Terry, G. R., \& Rue, L. W. (1988). Dasar-Dasar Manajemen. Alih bahasa: G. A. Ticoalu. Jakarta: Bina Aksara.

Waweru, N. M., Munyoki, E., \& Uliana, E. (2008). The Effects of Behavioral Factors in Investment Decision-making: A Survey of Institutional Investors Operating at the Nairobi Stock Exchange. International Journal of Business and Emerging Markets, 1(1), 24-41.

Wardani, A. K., \& Lutfi, L. (2017). Pengaruh Literasi Keuangan, Experienced Regret, Risk Tolerance, dan Motivasi pada Keputusan Investasi Keluarga dalam Perspektif Masyarakat Bali. Journal of Business and Banking, 6(2), 195-214.

Wulandari, D. A., \& Iramani, Rr. (2014). Studi Experienced Regret, Risk Tolerance, Overconfidance dan Risk Perception pada Pengambilan Keputusan Investasi. Journal of Business and Banking, 4(1), 55-66. 